\title{
KEBIJAKAN PENGHAPUSAN SANKSI PIDANA TERHADAP TINDAK PIDANA LINGKUNGAN HIDUP DALAM UNDANG-UNDANG NOMOR 11 TAHUN 2020 TENTANG CIPTA KERJA
}

\author{
Alfikri \\ Mahasiswa Magister IImu Hukum Fakultas Hukum \\ Universitas Gadjah Mada \\ JI. Sosio Yustisia No. 1, Bulaksumur, Kab. Sleman, D.I. Yogyakarta \\ E-mail : alfikrilubis.7@gmail.com
}

\begin{abstract}
The formation of the Employment Creation law is directed at harmonization with regard to several legislative materials which are considered overlapping. One of the interesting topics to examine in Law Number 11 of 2020 concerning Employment Creation is the elimination of criminal sanctions against criminal acts of the Environment replaced with administrative sanctions. This provision is seen in Article 23 point 37 which changes Article 102 in Law Number 32 Year 2009 concerning Environmental Protection and Management. The amendment to Article 82 $B$ in the Employment Creation Law only takes the form of administrative sanctions and does not include the types of criminal sanctions that can be imposed. The elimination of criminal sanctions against environmental crimes which are replaced by administrative sanctions signals the weakening of law enforcement against the environment. Meanwhile, environmental problems are getting bigger, wider and more serious. The problem is not only local or translocal, but regional, national, transnational and global in nature. Criminal sanctions are still considered to be the most effective and ultimate sanctions in tackling a crime, especially since the crime rate gives a very large loss.
\end{abstract}

\section{Keywords: Abolition of criminal sanctions, environmental crimes,} administrative sanctions

\begin{abstract}
Abstrak
Pembentukan undang-undang Cipta Kerja diarahkan pada harmonisasi terkait dengan beberapa materi peraturan perundang-undangan yang dianggap saling tumpang tindih. Salah satu topik yang menarik untuk ditelaah dalam Undang-Undang Nomor 11 Tahun 2020 tentang Cipta Kerja tersebut adalah penghapusan sanksi pidana terhadap tindak pidana
\end{abstract}


Lingkungan Hidup diganti dengan sanksi administrasi. Ketetuan tersebut dalam dilihat dalam Pasal 23 angka 37 yang merubah Pasal 102 didalam Undang-Undang Nomor 32 Tahun 2009 tentang Perlindungan dan Pengelolaan Lingkungan Hidup. Perubahan Pasal 82 B dalam UndangUndang Cipta Kerja hanya berupa sanksi administrasi dan tidak mencantumkan jenis sanksi pidana yang dapat dijatuhkan. Penghapusan sanksi pidana terhadap tindak pidana Lingkungan Hidup yang diganti dengan sanksi administrasi memberikan sinyal semakin melemahnya penegakan hukum terhadap lingkungan hidup. Sementara masalah lingkungan hidup semakin lama semakin besar, meluas, dan serius. Persoalannya bukan hanya bersifat lokal atau translokal saja, tetapi sudah bersifat regional, nasional, transnasional, dan global. Sanksi pidana masih dianggap sebagai sanksi yang paling ampuh dan pamungkas dalam menanggulangi suatu kejahatan apalagi tingkat kejahatan tersebut memberikan kerugian yang sangat besar.

Kata Kunci: Penghapusan sanksi pidana, tindak pidana lingkungan Hidup, sanksi administrasi

\section{Pendahuluan}

\section{a. Latar Belakang}

Sejak awal kehadiran RUU Ciptakerja dalam program legislasi nasional sudah mendapatkan beragam respon. Klaim dari Pemerintah dan DPR RI menyatakan bahwa kehadiran RUU Cipta Kerja akan membuka peluang investasi dan lain sebagainya terutama dalam hal pengelolaan dan pemanfaatan lingkungan hidup. Salah satu topik yang menarik untuk ditelaah dalam Undang-Undang Nomor 11 Tahun 2020 tentang Cipta Kerja tersebut adalah penghapusan sanksi pidana terhadap tindak pidana Lingkungan Hidup diganti dengan sanksi administrasi. Ketetuan tersebut dalam dilihat dalam Pasal 23 angka 37 yang merubah Pasal 102 didalam Undang-Undang Nomor 32 Tahun 2009 tentang Perlindungan dan Pengelolaan Lingkungan Hidup. Perubahan Pasal 82 B dalam Undang-Undang Cipta Kerja hanya berupa sanksi administrasi dan tidak mencantumkan jenis sanksi pidana yang dapat dijatuhkan. 
Hal tersebut tentu menjadi catatan khusus mengingat permasalahan pencemaran atau perusakan lingkungan hidup sampai saat ini masih mendapat sorotan. Terjadinya pencemaran atau perusakan lingkungan hidup oleh suatu industri, maka seyogyanya negaralah yang pertama sekali mengambil tanggungjawab untuk memberikan perlindungan. pencemaran atau perusakan lingkungan hidup itu sendiri, maka pihak-pihak yang bersengketa atau pihak-pihak yang seyogyanya saling berhadapan adalah pemerintah dengan industri/korporasi yang disangka melakukan tindakan pencemaran atau perusakan lingkungan hidup. ${ }^{1}$

Masalah lingkungan hidup semakin lama semakin besar, meluas, dan serius. Persoalannya bukan hanya bersifat lokal atau translokal saja, tetapi sudah bersifat regional, nasional, transnasional, dan global. Dampak-dampak yang terjadi terhadap masalah lingkungan tidak hanya terkait pada satu atau dua segi saja, tetapi saling berkaitan yang sesuai dengan sifat lingkungan yang memiliki hubungan yang luas dan saling mempengaruhi secara keseluruhan. ${ }^{2}$ Akan tetapi dalam hal ini, Negara justru merubah kebijakan penegakan hukum lingkungan.

Ketentuan pidana sebagaimana di atur dalam UUPPLH dimaksudkan untuk melindungi lingkungan hidup dengan memberikan ancaman sanksi pidana. ${ }^{3}$ Dalam spektrum penegakan hukum lingkungan, pidana dianggap sebagai upaya pengendalian pencemaran dan perusakan lingkungan, substansi pemidanaan merupakan reaksi atas delik lingkungan yang mengandung suatu tujuan ideal dalam tataran filosofis untuk memberikan perlindungan hukum

${ }^{1}$ Yudelmi, M. Chairul Idra, Pertanggungjawaban Korporasi Dalam Tindak Korporasi Dalam Tindak Pidana Lingkungan Hidup, Legalitas Edisi Juni 2010 Volume I Nomor 2, hlm. 188-189.

${ }^{2}$ Eric Rahmanul Hakim, Penegakan Hukum Lingkungan Indonesia Dalam Aspek Kepidanaan, Jurnal IImu Hukum, Volume 11 Nomor 1, April 2020, hlm. 44-45.

${ }^{3}$ Erwin Susanto, Penerapan Sanksi Pidana Terhadap Penanggung Jawab Usaha Yang Membuang Bahan Berbahaya dan Beracun (B3) Menurut Undang-Undang Nomor 32 Tahun 2009 tentang Perlindungan dan Pengelolaan Lingkungan Hidup, Lex Crimen Vol. VIII/No. 6/Jun/2019, hlm. 38. 
terhadap kualitas lingkungan sebagai bagian integral dari hakikat "environmental protection" bagi masyarakat. Dalam hal ini, bahwa pemidanaan bukan semata-mata karena telah terjadinya suatu delik, tetapi lebih dari itu agar jangan diperbuat lagi delik itu. ${ }^{4}$ Sehingga dengan penghapusan sanksi pidana dalam Undang-Undang Nomor 11 Tahun 2020 tentang Cipta Kerja, akan semakin melemahkan penegakan lingkungan hidup.

Berdasarkan latar belakang tersebut diatas, maka Penulis tertarik untuk melakukan kajian secara mendalam permasalahan ini dengan judul 'Kebijakan Penghapusan Sanksi Pidana terhadap Tindak Pidana Lingkungan Hidup dalam Undang-Undang Nomor 11 Tahun 2020 tentang Cipta Kerja”.

\section{b. Tujuan Penelitian}

Adapun tujuan yang hendak dicapai dalam penelitian ini adalah sebagai berikut:

1) Untuk mengetahui kebijakan penghapusan sanksi pidana terhadap tindak pidana lingkungan hidup dalam Undang-Undang Nomor 11 Tahun 2020 tentang Cipta Kerja.

\section{c. Manfaat Penelitian}

1) Penelitian ini untuk menambah pengetahuan dan pemahaman penulis khususnya mengenai masalah yang diteliti.

2) Sebagai sumber informasi yang bermanfaat bagi pengembangan ilmu hukum khususnya mengenai kebijakan penghapusan sanksi pidana terhadap tindak pidana lingkungan hidup dalam UndangUndang Nomor 11 Tahun 2020 tentang Cipta Kerja.

\footnotetext{
${ }^{4}$ Andi Hamzah dan Siti Rahayu, Suatu Tinjauan Ringkas Sistem Pemidanaan di
} Indonesia, Akademika Pressindo, Jakarta, 1983, hlm, 19-24 


\section{Tinjaun Pustaka}

\section{a. Tindak Pidana}

Tindak pidana merupakan pengertian dasar dalam hukum pidana (yuridis normatif). Kejahatan atau perbuatan jahat bisa diartikan secara yuridis atau kriminologis. Kejahatan atau perbuatan jahat dalam arti yuridis normatif adalah perbuatan seperti yang terwujud in abstracto dalam peraturan pidana. Tindak pidana sering juga disebut dengan kata "delik". Dalam Kamus Besar Bahasa Indonesia, arti delik diberi batasan sebagai berikut: "Perbuatan yang dapat dikenakan hukuman karena merupakan pelanggaran terhadap undang-undang tindak pidana. ${ }^{5}$ Moeljatno menggunakan istilah tindak pidana, di mana perkataan "Tindak" tidak menunjuk pada hal abstrak seperti perbuatan, tapi sama dengan perkataan peristiwa yang juga menyatakan keadaan kongkrit, seperti kelakuan, gerak-gerik atau sikap jasmani, hal mana lebih dikenal dalam tindak tanduk, tindakan dan bertindak. ${ }^{6}$

\section{b. Pidana}

Pidana berasal dari kata Straf (Belanda), pada dasarnya dapat dikatakan sebagai suatu penderitaan yang sengaja dikenakan atau dijatuhkan kepada seseorang yang telah terbukti bersalah melakukan suatu tindak pidana. Menurut Moeljatno dan Barda Nawawi Arief, istilah hukuman yang berasal dari kata straf, merupakan suatu istilah yang konvensional. Moeljatno menggunakan istilah yang inkonvensional, yaitu pidana. ${ }^{7}$ Menurut Andi Hamzah, ahli hukum Indonesia membedakan istilah hukuman dengan pidana, yang dalam bahasa Belanda dikenal dengan istilah straf. Istilah hukuman adalah istilah umum yang dipergunakan untuk semua jenis sanksi baik dalam ranah hukum perdata, administratif, disiplin dan pidana, sedangkan hlm. 37.

${ }^{5}$ Kansil C.S.T, Pokok-Pokok Hukum Pidana, Pradnya Paramita, Jakarta: 2004,

${ }_{7}^{6}$ Moeljatno, Asas-Asas Hukum Pidana, Rineka Cipta, Jakarta: 2008, hIm. 69.

7 Muladi dan Barda Nawawi Arief, Teori-Teori dan Kebijakan Pidana, (Bandung: Alumni, 2005), hlm.1 
istilah pidana diartikan secara sempit yaitu hanya sanksi yang berkaitan dengan hukum pidana. ${ }^{8}$

Menurut Satochid Kartanegara, bahwa hukuman (pidana) itu bersifat siksaan atau penderitaan, yang oleh undang-undang hukum pidana diberikan kepada seseorang yang melanggar sesuatu norma yang ditentukan oleh undang- undang hukum pidana, dan siksaan atau penderitaan itu dengan keputusan hakim dijatuhkan terhadap diri orang yang dipersalahkan itu. Sifat yang berupa siksaan atau penderitaan itu harus diberikan kepada hukuman (pidana), karena pelanggaran yang dilakukan oleh seseorang terhadap norma yang ditentukan oleh undang- undang. ${ }^{9}$

\section{c. Penelitian Terdahulu}

Dasar atau acuan yang berupa teori atau temuan melalui hasil berbagai penelitian sebelumnya merupakan hal sangat perlu dan dapat dijadikan sebagai data pendukung. Salah satu data pendukung yang menurut peneliti perlu dijadikan bagian tersendiri adalah penelitian terdahulu yang relevan dengan permasalahan yang sedang dibahas dalam penelitian ini. Dalam hal ini fokus penelitian terdahulu yang dijadikan acuan adalah terkait dengan masalah pembinaan. Untuk memudahkan pemahaman terhadap penelitian terdahulu dapat dilihat sebagai berikut:

Rumbadi dengan judul Analisis Terhadap Premium Remedium Terkait Sanksi Hukum Lingkungan. 2015. Kifly G. Kumolontang dengan judul Pemidanaan Dalam Tindak Pidana Lingkungan Hidup, Fakultas Hukum Unsrat, Lex Crimen Vol. VII/No. 2 /April/2018. Selanjutnya penelitian Erwin Susanto dengan judul "Penerapan Sanksi Pidana Terhadap Penanggung Jawab Usaha Yang Membuang Bahan Berbahaya dan Beracun (B3) Menurut Undang-Undang Nomor 32 Tahun 2009 tentang Perlindungan dan Pengelolaan Lingkungan Hidup,

\footnotetext{
${ }^{8}$ Andi Hamzah, Asas - Asas Hukum Pidana, (Jakarta: Rineka Cipta, 2008),
} hlm.27.

${ }^{9}$ Ibid, hlm. 27 
Lex Crimen Vol. VIII/No. 6/Jun/2019. Hasil penelitian tersebut menunjukkan bahwa sanksi pidana masih dianggap sebagai sanksi yang ampuh dalam menanggulangi suatu tindak pidana.

\section{Metode Penelitian}

Penelitian hukum ini merupakan penelitian hukum normatif yang berorientasikan kepada norma-norma hukum positif (ius constitutum) yaitu: penelitian yang lebih fokus kepada implementasi norma-norma dan asas-asas hukum positif, berupa pendekatan peraturan perundangundangan (statatutes approach) yang relevan dengan kajian rumusan masalah issu hukum dalam penelitian hukum ini. Penelitian ini bertitik tolak dari bidang-bidang tata hukum (tertulis) tertentu dengan cara mengadakan identifikasi terlebih dahulu terhadap kaidah-kaidah hukum yang telah dirumuskan di dalam perundang-undangan tertentu. Dalam penelitian ini penulis melakukan penelitian terhadap asas-asas hukum yang merupakan patokan-patokan berprilaku atau bersikap tidak pantas dengan memanfaatkan metode deskriptif. ${ }^{10}$ Penelitian ini mengkaji tentang Kebijakan Penghapusan Sanksi Pidana terhadap Tindak Pidana Lingkungan Hidup dalam Undang-Undang Nomor 11 Tahun 2020 tentang Cipta Kerja.

Di dalam penelitian ini, analisis data yang dilakukan adalah analisis kualitatif, merupakan tata cara penelitian yang menghasilkan data deskriptif, yaitu apa yang dinyatakan tertulis. ${ }^{11}$ Selanjutnya, penulis menarik kesimpulan secara deduktif, yaitu menarik kesimpulan dari halhal yang bersifat umum kepada hal-hal yang bersifat khusus. Dimana dalam mendapatkan kesimpulan dimulai dengan melihat faktor-faktor yang nyata dan diakhiri dengan penarikan suatu kesimpulan yang juga merupakan fakta dimana kedua fakta tersebut dijembatani oleh teoriteori.

${ }^{10}$ Zainuddin Ali, Metode Penelitian Hukum, Sinar Grafika, Jakarta: 2009, hlm. 25.

${ }^{11}$ Soerjono Soekanto, Pengantar Penelitian Hukum, UI Press, Jakarta, 1983, hlm. 32 


\section{Hasil Penelitian dan Pembahasan}

1. Kebijakan Penghapusan Sanksi Pidana Terhadap Tindak Pidana Lingkungan Hidup dalam Undang-Undang Nomor 11 Tahun 2020 tentang Cipta Kerja

Undang-Undang Nomor 11 Tahun 2020 tentang Cipta Kerja memiliki permasalahan permasalahan krusial apabila ditinjau dari aspek pengaturan pengaturan sanksi di dalam bidang-bidang kebijakan terutama dalam klaster lingkungan hidup. Kebijakan penghapusan sanksi pidana terhadap tindak pidana Lingkungan Hidup yang diganti dengan sanksi administrasi dapat dilihat dalam Pasal 82 B Undang-Undang Nomor 11 Tahun 2020 tentang Cipta Kerja. Adapun bunyi Pasal 82 B ayat (2) dan ayat (3) Undang-Undang Nomor 11 Tahun 2020 tentang Cipta Kerja yaitu :

1) Setiap orang yang melakukan usaha dan/atau kegiatan yang memiliki Perizinan Berusaha sebagaimana dimaksud dalam Pasal 24 ayat (5), Pasal 34 ayat (3), Pasal 36 ayat (1), Pasal 59 ayat (1), Pasal 59 ayat (4) atau Persetujuan dari Pemerintah sebagaimana dimaksud dalam Pasal 20 ayat (3) huruf b atau Pasal 61 yang tidak sesuai dengan kewajiban dalam Perizinan Berusaha atau Persetujuan Pemerintah dan/atau melanggar ketentuan Peraturan Perundang-undangan di Bidang Perlindungan dan Pengelolaan Lingkungan Hidup, dikenai sanksi administratif.

2) Setiap orang yang melakukan pelanggaran larangan sebagaimana dimaksud dalam Pasal 69, yaitu: a. melakukan perbuatan yang mengakibatkan pencemaran dan/atau perusakan lingkungan hidup sebagaimana dimaksud dalam Pasal 69 huruf a, dimana perbuatan tersebut dilakukan karena kelalaian dan tidak mengakibatkan bahaya kesehatan manusia dan/atau luka dan/atau luka berat, dan/atau matinya orang dikenai sanksi administratif dan mewajibkan kepada Penanggung Jawab perbuatan itu untuk melakukan pemulihan fungsi lingkungan hidup dan/atau tindakan 
lain yang diperlukan; atau b. menyusun Amdal tanpa memiliki sertifikat kompetensi penyusun Amdal sebagaimana dimaksud dalam Pasal 69 huruf i dikenai sanksi administratif.

3) Setiap orang yang karena kelalaiannya melakukan perbuatan yang mengakibatkan dilampauinya baku mutu udara ambien, baku mutu air, baku mutu air laut, atau kriteria baku kerusakan lingkungan hidup yang tidak sesuai dengan Perizinan Berusaha yang dimilikinya dikenai sanksi administratif.

Di dalam Pasal 82C dijelaskan bahwa Sanksi administratif sebagaimana dimaksud dalam Pasal 82A dan Pasal 82B ayat (1), ayat (2), dan ayat (3) berupa Teguran tertulis, Paksaan pemerintah, Denda administratif, Pembekuan Perizinan Berusaha dan Pencabutan Perizinan Berusaha. Sementara dalam Undang-Undang Nomor 32 Tahun 2009 tentang Perlindungan dan Pengelolaan Lingkungan Hidup di dalam Pasal 102 menyatakan bahwa "Setiap orang yang melakukan pengelolaan limbah B3 tanpa izin sebagaimana dimaksud dalam Pasal 59 ayat (4), dipidana dengan pidana penjara paling singkat 1 (satu) tahun dan paling lama 3 (tiga) tahun dan denda paling sedikit Rp1.000.000.000,00 (satu miliar rupiah) dan paling banyak Rp3.000.000.000,00 (tiga miliar rupiah)”. Lebih lanjut dalam Pasal 103 bahwa "Setiap orang yang menghasilkan limbah B3 dan tidak melakukan pengelolaan sebagaimana dimaksud dalam Pasal 59, dipidana dengan pidana penjara paling singkat 1 (satu) tahun dan paling lama 3 (tiga) tahun dan denda paling sedikit Rp1.000.000.000,00 (satu miliar rupiah) dan paling banyak Rp3.000.000.000,00 (tiga miliar rupiah)". Jika dicermati dalam UU PPLH, sanksi pidana dalam dinyatakan cukup jelas dan tegas.

Pengaturan klaster lingkungan hidup dalam Undang-Undang Nomor 11 Tahun 2020 tentang Cipta Kerja terutama penghapusan sanksi pidana sangat tidak tepat. Hal ini karena, dalam ketentuan penghapusan sanksi pidana tidak memberikan pilihan yang 
dimungkinkan efektivitas sanksi administrasi apabila sanksi administrasi tersebut tidak tidak dipatuhi. Walaupun wewenang menerapkan sanksi administrasi pada dasarnya adalah merupakan suatu discretionary power. Penerapan instrumen hukum administrasi bertujuan agar perbuatan atau pengabaian yang melanggar hukum atau tidak memenuhi persyaratan, berhenti atau mengembalikan kepada keadaan semula (sebelum ada pelanggaran). Oleh karena itu, fokus dari penerapan sanksi administratif adalah perbuatannya, sedangkan sanksi dari hukum pidana adalah orangnya. ${ }^{12}$ Sementara penerapan sanksi administrasi adalah merupakan konsekuensi lanjutan dari tindakan pengawasan pengelolaan lingkungan hidup.

Menurut penulis, penghapusan sanksi pidana tersebut berakibat bahwa sanksi administrasi tidak memiliki ketegasan dalam pengawasannya. Dengan demikian Pemberian sanksi administrasi dalam Pasal 82B UU Cipta Kerja tergolong memudahkan dikarenakan pemberlakuan sanksi administrasi tidak diikuti dengan sanksi lain atas pelanggaran tersebut. Selain itu, memberlakuan sanksi dalam Pasal 82 B UU Cipta Kerja ini dinilai kurang tegas dan terlalu berpihak kepada pelaku usaha dalam hal mengelola lingkungan. Sehingga pengulangan perbuatan sangat dimungkinkan kembali.

Sementara masalah lingkungan hidup semakin lama semakin besar, meluas, dan serius. Persoalannya bukan hanya bersifat lokal atau translokal saja, tetapi sudah bersifat regional, nasional, transnasional, dan global. Dampak-dampak yang terjadi terhadap masalah lingkungan tidak hanya terkait pada satu atau dua segi saja, tetapi saling berkaitan yang sesuai dengan sifat lingkungan yang memiliki hubungan yang luas dan saling mempengaruhi secara keseluruhan. $^{13}$

\footnotetext{
${ }^{12}$ Moh. Fadil, Mukhlish dan Mustafa Lutfi. Hukum dan Kebijakan Lingkungan, UB Press. Malang, 2016, hlm. 80.

${ }^{13}$ Eric Rahmanul Hakim, Penegakan Hukum Lingkungan Indonesia Dalam Aspek Kepidanaan, Jurnal Ilmu Hukum, Volume 11 Nomor 1, April 2020, hlm. 44-45.
} 
Terjadinya pencemaran, kerusakan lingkungan kebanyakan dilakukan dalam konteks menjalankan suatu usaha ekonomi dan sering juga merupakan sikap penguasa maupun pengusaha yang tidak menjalankan atau melalaikan kewajibannya dalam pengelolaan lingkungan hidup. ${ }^{14}$ Ketentuan hukum pidana ditemukan dalam Pasal 41 Undang-Undang Belgia. Pasal ini menghukum, antara lain, siapa saja yang melanggar ketentuan Undang-undang atau perintah eksekutif yang dibuat di bawahnya. Lebih khusus lagi menghukum siapa saja yang, dengan melanggar Pasal 5 , membuang air limbah ke air permukaan tanpa izin atau melanggar kondisi izin. Pengamat hukum Jerman pun berkomentar kodifikasi pidana yang mengecualikan kejahatan yang kurang serius, akan meningkatkan efek jera hukum pidana lingkungan, dan akan memfasilitasi penuntutan. ${ }^{15}$

Sanksi pidana sebagai salah satu sanksi yang diatur didalamnya harus diterapkan dengan tujuan untuk melindungi lingkungan hidup, sehingga diperlukan suatu sistem pemidanaan di bidang lingkungan hidup yang berbasis konservasi lingkungan hidup demi terwujudnya pengelolaan lingkungan hidup yang disertai dengan perlindungan dan pelestarian lingkungan hidup. ${ }^{16}$ Maka dalam menanggulangi tindak pidana lingkungan hidup perlu diberlakukan sanksi pidana secara primum remidium, tindak pencemaran dan perusakan lingkungan hidup perlu disikapi dengan tegas melalui penerapan sanksi-sanksi pidana. Namun dilain sisi pemidanaan juga

\footnotetext{
${ }^{14}$ Wahono Baoed, Penegakan Hukum Lingkungan melalui Ketentuan-ketentuan Hukum Pidana, Mandar Maju, Jakarta: 1996, hlm. 42.

${ }^{15}$ Michael Faure, The Revolution in Environmental Criminal Law in Europe, Virginia Environmental Law Journal, Vol. 35, No. 2 (2017), hlm. 325-326.

${ }^{16}$ Eko Setiawan, Putusan Pemidanaan Sebagai Pengganti Denda yang tidak dibayar oleh korporasi dalam tindak pidana lingkungan hidup, Badamai Law Journal, Vol. 4, Issues 1, Maret 2019, hlm.62.
} 
dimaksudkan untuk memperbaiki keadaan juga mencegah orang lain melakukan tindak pidana yang serupa. ${ }^{17}$

Pembuat kebijakan masih harus melihat efisiensi dan/atau efektivitas biaya instrumen penegakan untuk melindungi lingkungan. Perbedaan instrumen hukum, seperti sanksi pidana atau administratif, memiliki perbedaan terkait dengan biaya serta dampak yang berbeda pada perilaku pelaku potensial. ${ }^{18}$ Keberadaan instrumen legal diharapkan mampu meminimalisasikan resiko ekelogis yang timbul akibat dampak pembangunan yang tidak memperhatikan segi-segi kelangsungan lingkungan hidup. Namun demikian, instrumen legal tersebut harus juga dibaregi dengan upaya yang sungguh-sungguh dari negara untuk melakukan law enforcement terhadap siapa saja yang telah melakukan kerusakan terhadap lingkungan hidup. Disamping itu, kesadaran masyarakat akan pentingnya menjaga kualitas lingkungan hidup yang sehat harus terus ditumbuhkan. Pengelolaan lingkungan hidup memerlukan pengaturan hukum agar masyarakat mempunyai dasar hukum untuk berperan serta dalam pengelolaan lingkungan hidup yang berbasis pada pembangunan berkelanjutan. $^{19}$

Penegakan hukum pidana lingkungan menurut UU PPLH, dikenal adanya ancaman hukuman minimum, di samping ancaman hukuman maksimum, perluasan alat bukti, pemidanaan bagi pelanggaran baku mutu, keterpaduan penegakan hukum pidana, dan pengaturan tindak pidana korporasi. ${ }^{20}$ Penegakan hukum terhadap

${ }^{17}$ Sri Sufiyatidan, Munsyarif Abdul Chalim, Kebijakan Hukum Pidana dalam Menanggulangi Tindak Pidana Lingkungan Hidup, Jurnal Hukum, Vol. 12. 2017, hlm. 463

${ }^{18}$ Michael G. Faure and Katarina Svatikova, Criminal orAdministrative Law to Protect the Environment? Evidence from Western Europe, Journal of Environmental Law, 24:2 (2012), hlm. 258.

${ }^{19}$ Moh. Fadil, Mukhlish dan Mustafa Lutfi. Hukum dan Kebijakan Lingkungan, UB Press. Malang, 2016, hlm. 178.

${ }^{20}$ Fahriza Havinanda. Politik Hukum Dalam Pembaharuan Sistem Hukum Pidana Lingkungan Dan Dampaknya Terhadap Efektivitas Penegakan Hukum Tindak Pidana 
kejahatan lingkungan hidup tidak hanya diarahkan kepada penegakan keadilan hukum, tetapi juga harus diarahkan pada penegakan keadilan sosial dan ekonomi secara simultan. Artinya bahwa tidak hanya memberikan hukuman/sanksi pidana kepada pelaku dengan sanksi yang seberat-beratnya, melainkan juga agar kerugian negara yang diakibatkan oleh perbuatan pelaku kejahatan itu dapat kembali seperti semula dalam waktu yang tidak terlalu lama. ${ }^{21}$

Undang-undang terkait pengelolaan lingkungan hidup memuat ketentuan yang tegas tentang penerapan asas Ultimum Remedium dan Primum Remedium. Ketentuan ini sudah termuat sejak adanya undang-undang pengelolaan lingkungan hidup pada tahun 1997, yang kemudian mengalami perubahan pada undang-undang lingkungan tahun 2009. ${ }^{22}$ Undang undang terkait pengelolaan lingkungan hidup, Undang Undang Nomor 4 tahun 1982 atau UULH, Undang Undang Nomor 23 tahun 1997 atau UUPLH dan Undang undang Nomor 32 tahun 2009 atau UUPPLH telah memuat ketetentuan yang tegas mengenai sanksi administratif, sanksi perdata maupun sanksi pidana.

Sehingga Pasal 105 RUU Cipta Kerja mengubah Pasal 72 -76 UU PPLH. Pengubahan tersebut berakibat bahwa sanksi administrasi tidak memiliki ketegasan dalam pengawasannya. Dengan demikian Pemberian sanksi dalam Pasal 105 RUU Cipta Kerja tergolong memudahkan dikarenakan pemberlakuan sanksi administrasi tidak diikuti dengan sanksi lain seperti penutupan lahan maupun pembekuan lahan atas pelanggaran dalam Selain itu, memberlakuan sanksi dalam Pasal 105 RUU Cipta Kerja ini dinilai kurang tegas dan terlalu berpihak kepada pelaku usaha dalam hal ini adalah pemilik

Lingkungan Hidup. Jurnal Hukum dan Kemasyarakatan Al-Hikmah, Vol. 1 No. 1, September 2020, hlm.114.

21 Nurul Widhanita Y. Badilla dan Rudini Hasyim Rado, Harmonisasi Hukum Pidana di Bidang di Bidang Lingkungan Hidup Dalam Rangka Pembaharuan Hukum Pidana Lingkungan. Jurnal Restorative Justice, Vol. 3 Nomor 1, Mei 2019, hlm. 24-25.

${ }_{22}$ Masrudi Muchtar, 2015, Sistem Peradilan Pidana di Bidang Perlindungan \& Pengelolaan Lingkungan, Prestasi Pustaka, Jakarta, hlm. 81 
perkebunan.

Sanksi pidana masih dianggap sebagai sanksi yang paling ampuh dan pamungkas dalam menanggulangi suatu kejahatan apalagi tingkat kejahatan tersebut memberikan kerugian yang sangat besar. Maka dalam hal ini negara harus bertindak dan memberikan reaksi terhadap pelanggar hukum dengan menjatuhkan sanksi yang sesuai dengan karakteristik kejahatan maupun pelakunya. ${ }^{23}$ Hukum pidana ditujukan untuk melindungi masyarakat terhadap tindak pidana yang menimbulkan kerugian atau setidak-tidaknya membahayakan kepentingan hukum. Pelaku yang dijatuhi pidana itu dijadikan contoh oleh masyarakat agar masyarakat tidak meniru dan melakukan perbuatan yang serupa dengan penjahat itu. ${ }^{24}$ Sehingga pelaku pencemaran atau perusakan lingkungan tidak ada lagi yang lolos dari ancaman pidana.

\section{Kesimpulan}

Penghapusan sanksi pidana dalam Undang-Undang Nomor 11 Tahun 2020 tentang Cipta Kerja berakibat bahwa sanksi administrasi tidak memiliki ketegasan dalam pengawasannya. Pemberian sanksi administrasi dalam Pasal 82B UU Cipta Kerja tergolong memudahkan dikarenakan pemberlakuan sanksi administrasi tidak diikuti dengan sanksi lain atas pelanggaran tersebut. Selain itu, memberlakuan sanksi dalam Pasal 82 B UU Cipta Kerja ini dinilai kurang tegas dan terlalu berpihak kepada pelaku usaha dalam hal mengelola lingkungan. Sehingga pengulangan perbuatan sangat dimungkinkan kembali.

Seharusnya tidak perlu dilakukan Penghapusan Sanksi Pidana terhadap Tindak Pidana Lingkungan Hidup dalam Undang-Undang Nomor 11 Tahun 2020 tentang Cipta Kerja. Penerapan sanksi pidana tetap dicantum jika penerapan sanksi sanksi administrasi tidak efektif bagi para

${ }^{23}$ M. Ali Zaidan, Kebijakan Kriminal, Sinar Grafika, Jakarta, 2016, hlm.130

24 Adami Chazawi, Stelsel Pidana, Tindak Pidana, Teori-Teori Pemidanaan \& Batas Berlakunya Hukum Pidana, PT. Raja Grafindo Persada, Jakarta, 2007, hlm 16 
pelaku tindak pidana lingkungan hidup. Maka dalam menanggulangi tindak pidana lingkungan hidup perlu diberlakukan sanksi pidana secara primum remidium, tindak pencemaran dan perusakan lingkungan hidup perlu disikapi dengan tegas melalui penerapan sanksi-sanksi pidana. Agar pemidanaan yang dilakukan dapat mencegah orang lain melakukan tindak pidana yang serupa. 


\section{DAFTAR PUSTAKA}

\section{Buku}

Adami Chazawi, Stelsel Pidana, Tindak Pidana, Teori-Teori Pemidanaan \& Batas Berlakunya Hukum Pidana, PT. Raja Grafindo Persada, Jakarta, 2007.

Andi Hamzah dan Siti Rahayu, Suatu Tinjauan Ringkas Sistem Pemidanaan di Indonesia, Akademika Pressindo, Jakarta, 1983.

Andi Hamzah, Asas - Asas Hukum Pidana, Rineka Cipta, Jakarta, 2008.

Kansil C.S.T, Pokok-Pokok Hukum Pidana, Pradnya Paramita, Jakarta: 2004.

M. Ali Zaidan, Kebijakan Kriminal, Sinar Grafika, Jakarta, 2016, hlm.130

Masrudi Muchtar, 2015, Sistem Peradilan Pidana di Bidang Perlindungan \& Pengelolaan Lingkungan, Prestasi Pustaka, Jakarta.

Moeljatno, Asas-Asas Hukum Pidana, Rineka Cipta, Jakarta: 2008.

Moh. Fadil, Mukhlish dan Mustafa Lutfi. Hukum dan Kebijakan Lingkungan, UB Press. Malang, 2016.

Muladi dan Barda Nawawi Arief, Teori-Teori dan Kebijakan Pidana, Bandung: Alumni, 2005.

Soerjono Soekanto, Pengantar Penelitian Hukum, UI Press, Jakarta, 1983.

Wahono Baoed, Penegakan Hukum Lingkungan melalui Ketentuanketentuan Hukum Pidana, Mandar Maju, Jakarta: 1996.

Zainuddin Ali, Metode Penelitian Hukum, Sinar Grafika, Jakarta: 2009.

\section{Jurnal}

Eko Setiawan, Putusan Pemidanaan Sebagai Pengganti Denda yang tidak dibayar oleh korporasi dalam tindak pidana lingkungan hidup, Badamai Law Journal, Vol. 4, Issues 1, Maret 2019.

Eric Rahmanul Hakim, Penegakan Hukum Lingkungan Indonesia Dalam Aspek Kepidanaan, Jurnal Ilmu Hukum, Volume 11 Nomor 1, April 2020.

Erwin Susanto, Penerapan Sanksi Pidana Terhadap Penanggung Jawab Usaha Yang Membuang Bahan Berbahaya dan Beracun (B3) 
Menurut Undang-Undang Nomor 32 Tahun 2009 tentang Perlindungan dan Pengelolaan Lingkungan Hidup, Lex Crimen Vol. VIII/No. 6/Jun/2019.

Fahriza Havinanda. Politik Hukum Dalam Pembaharuan Sistem Hukum Pidana Lingkungan Dan Dampaknya Terhadap Efektivitas Penegakan Hukum Tindak Pidana Lingkungan Hidup. Jurnal Hukum dan Kemasyarakatan Al-Hikmah, Vol. 1 No. 1, September 2020.

Michael Faure, The Revolution in Environmental Criminal Law in Europe, Virginia Environmental Law Journal, Vol. 35, No. 2 (2017).

Michael G. Faure and Katarina Svatikova, Criminal orAdministrative Law to Protect the Environment? Evidence from Western Europe, Journal of Environmental Law, 24:2 (2012).

Nurul Widhanita Y. Badilla dan Rudini Hasyim Rado, Harmonisasi Hukum Pidana di Bidang di Bidang Lingkungan Hidup Dalam Rangka Pembaharuan Hukum Pidana Lingkungan. Jurnal Restorative Justice, Vol. 3 Nomor 1, Mei 2019.

Sri Sufiyatidan, Munsyarif Abdul Chalim, Kebijakan Hukum Pidana dalam Menanggulangi Tindak Pidana Lingkungan Hidup, Jurnal Hukum , Vol. 12. 2017.

Yudelmi, M. Chairul Idra, Pertanggungjawaban Korporasi Dalam Tindak Korporasi Dalam Tindak Pidana Lingkungan Hidup, Legalitas Edisi Juni 2010 Volume I Nomor 2.

\section{Undang-Undang}

Undang-Undang Nomor 32 Tahun 2009 tentang Perlindungan dan Pengelolaan Lingkungan Hidup.

Undang-Undang Nomor 11 Tahun 2020 tentang Cipta Kerja. 